\title{
Kung Paano Aketchi Naging si TheKneejerkCritic
}

\section{Ricardo Espino Lopez \\ GMA Network - Entertainment, Talk/Variety}

Sinetchi ba itech feelingerong TheKneeJerkCritic at hungkapsmuks magreview-keme ng movies as if may K? The nerve! The nerve daw, o?!

Anu raw?

Sabi ko, sino nga ba si TheKneeJerkCritic and how dare he do movie reviews. As if!!!? Ganern.

Ang sagot, self-published blogger siya. Hindi siya nababasa sa magazine, e-zine, nor sa broadsheet. Ni hindi nga siya pinatos ng tabloids eh.

TheKneeJerkCritic ay isang blog na nagpufocus sa pag-rereview ng mga local at foreign films, at isama na rin ang ilang palabas sa teatro, habang gamit ang street-based off-the-cuff language with more than just a sprinkling of bekinese or gay lingo.

TheKneeJerkCritic is actually a spin-off ng una kong online alter ego, si IshnaVera, which I started aroung 2006. Diverse at walang direksyon pa ang sakop ng pagsusulat ko noon bilang IshnaVera at pasulpot-supot lang. Pag gusto ko lang humanash. 
Ooops sorry, force of habit. I mean, kapag mayroon lang akong gustong sabihin.

My first "review" was not really even an actual review. It was more a reaction piece, my personal take sa pelikula as an experience rather than a review about the movie.

See Evidence A, an early sample ng review ko of the groundbreaking pink indie film Ang Lihim ni Antonio [dinirhe ni Joselito Altarejos, Beyond the Box \& Viva Digital, 2008] (Pig. 1):

I missed catching Lihim ni Antonio nung ipinalabas ang director's cut nito last year yata. I managed to get hold of a copy recently and I excitedly popped it into the player.

Ang takbo ng Lihim goes like this:

... fast-forward, fast-forward, fast-forward.... play, rewind, play, rewind, play ... fast-forward, fast-forward ... play, rewind, play, rewind, play ... fast-forward. Stop. Eject.

Ay! May kwento ba? Sige try ko some other time wehehe. 


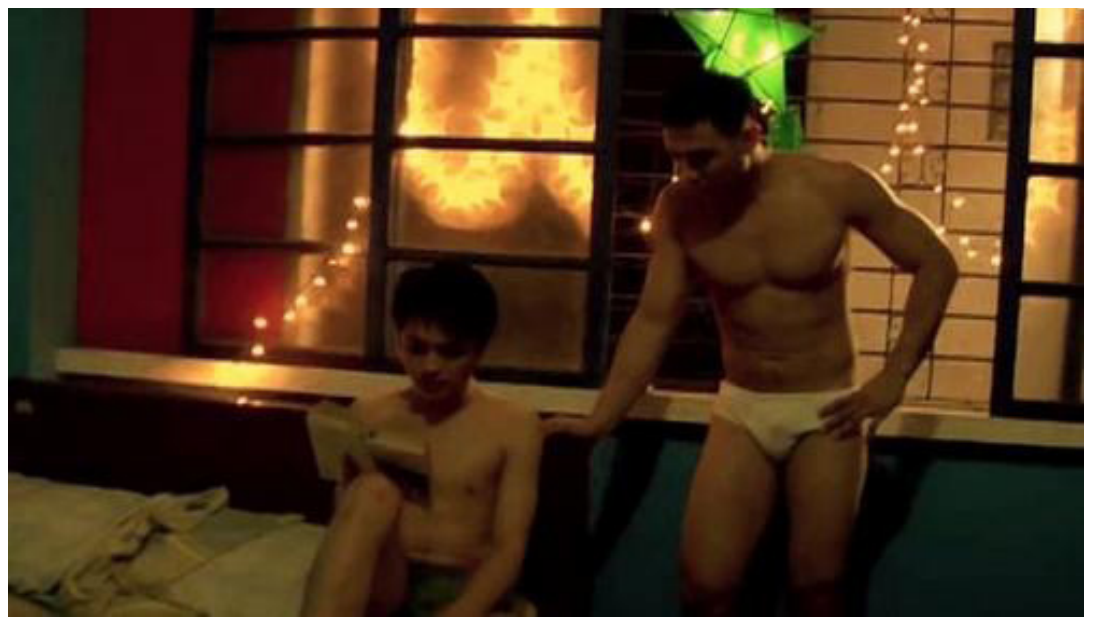

Pig. 1. Still picture ng Ang Lihim ni Antonio ni Joselito Altarejos. (Beyond the Box \& Viva Digital, 2008)

Well, apparently may audience ang ganitong piyesa kasi I eventually noticed na tuwing may "reviews" lang ako nakakakuha ng online engagement from my friends, who made up the totality of my reading population at that point.

It was around April 2015, na napagnilay-nilayan ko na karirin kaya ang pagrereview at gumawa ng entirely separate blog. Thus TheKneeJerkCritic was born.

So ito ang una kong post bilang The KneeJerk Critic, a review of the critically acclaimed but Oscar-snubbed masterpiece, Avengers: Age of Ultron [dinirhe ni Joss Whedon, Marvel Studios at Walt Disney Pictures, 2015], charot (Pig. 2): 
Eto ang cheat sheet ng kwento ng Age of Ultron:

Wham. Bam. Boom.

Yada-yada. Love angle. Yada-yada.

Boom. Bam. Wham. CGI efok.

Family ek. Balbon na dibdib ni Mark Ruffalo. Hopia-cum-emo.

Chase scene. Sprakatak. Tarakatat.

Eklavu. Eklavu. Hubad na Chris Helmsworth.

Jennylyn. Jennylyn. Robot gagawin kong kalbong Bollywood actor na may

mahiwagang bindi!

Bonggang-bonggang multi-hero fight-scene tableau.

Kaboom. Kablam. Death scene for major emo moment.

Climactic finish.

Epilogue segue to introduction of Avengers 2.0.

Credits.

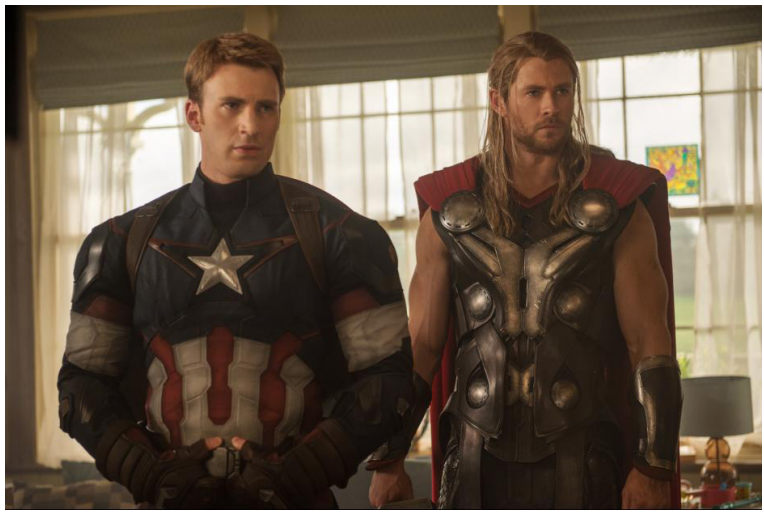

Pig. 2. Still picture ng Avengers: Age of Ultron ni Joss Whedon. (Marvel Studios at Walt Disney Pictures, 2015)

Hindi yan excerpt huh. Yan na yung buong review. Kinarir ko na yan nang lagay na 'yan. Wag nga kayo. Work in progress pa ako nun ok?

Char. 
So what qualified me to review movies? Huwell, aside from paying the exorbitant movie ticket price, waley. Bet ko lang humanash eh, buhkit ba? Balakayujan.

Cards on the table. I have no bachelor, master's, much less a doctorate degree in film or film appreciation to give me any credibility as a reviewer. Hindi nga ako nakatapos ng college eh. So I totally have no credentials as a film critic. Zero. None. Zilch. Nada. Gusto ko lang.

Though my work in media places me sa bandang laylayan ng hierarchy ng entertainment industry, wala akong koneksyon sa paggawa ng pelikula whatsoever.

What I am is a movie fan.

Or make that, a fan of movies.

Wala akong ilusyon na maging film connoisseur. Keber ako kung quirky indie film yan, o studio-released mainstream movie, o super-commercial fluff. Hindi ako isnabera. Rom-com, sci-fi, superhero blockbuster, awardsbait, o anime, basta nainteresan ko, papanoorin ko yan. Maski lumang reissue nga pinapatulan ko eh. Here's an excerpt ng review ko ng Himala [dinirhe ni Ishmael Bernal, Experimental Cinema of the Philippines, 1982] na pinanood ko 35 years after its original run (Pig. 3): 
Ang kwento ay umiikot sa barrio Cupang, isang puritang rural village na sinasabi ng mismong villagers eh isinumpang matuyot dahil meron raw silang pinagtabuyang leper noon na later on pinaniniwalaan nilang si Mama Mary in disguise.

Lagoat, inimbey niyo ang Mother of God!

Later, during a major-major solar eclipse, aba mukhang nag-return engagement si Mama Mary sa Cupang -- pero limited edition lang dahil kay Elsa lang siya nagpapakita.

Tapos nagkaroon si Elsa ng stigmata keme. Tapos, after that, nakakapaghealing na ang bakla, este ang visionary!

Parang mumurahing kolboy, nagpasalinsaling-bibig ang chismis ng faith healing and before you know it dinagsa na ng iba't-ibang uri ng maysakit ang balur ni Elsa kasunod ang mga paparazzi.

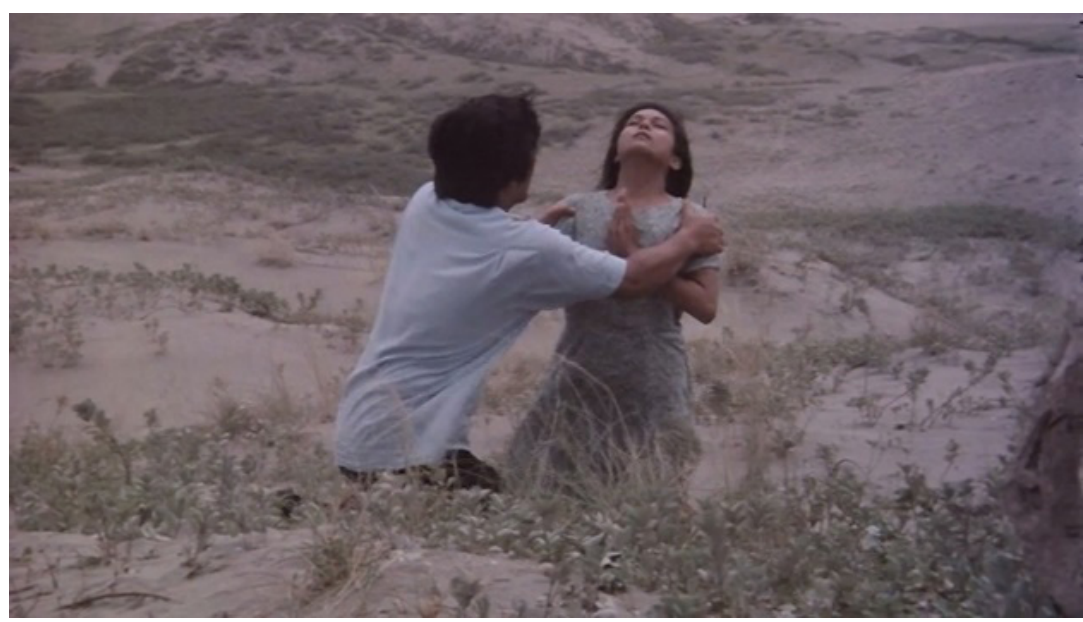

Pig. 3. Still pic ng Himala ni Ishmael Bernal. (Experimental Cinema of the Philippines, 1982) 
Nagga-gamble din ako sa mga movies na hindi ako sure kung maganda o hindi, especially indie film. Indie films kasi need the financial support ko as a viewer as well as kung ano mang exposure ang napoprovide ko as an online reviewer.

Nag-eeffort rin akong mag-binge watch ng entries ng local filmfest like MMFF, Pista Ng Pelikulang Pilipino, at Cinemalaya, in support of the local industry. Minsan it turns out na maganda pala yung movie at win ako, minsan naman chakaru so lose. Pero for commercial movies, kung feeling ko mapapangitan lang naman ako, I skip it na lang kasi wala akong balak na gumastos para inisin lang ang sarili ko. Bakla ako, hindi tanga, $O K$ ?

As a viewer, I prefer movies that touch me emotionally. I have nothing against intellectual movies pero mas bet ko yung kinikilig ako sa movies. Keri rin pag pinaiiyak. OK rin lang pag-isipin ako ng movie pero not too much pwede? Ayoko ng pelikulang masakit sa bangs, yun bang mahirap ispelengin at nagpapadeep. Ramdam mo naman yung nagpapa-high-falutin at pa-impress lang si director, di ba? Sorry, thank you next ka sa akin.

Ayoko rin ng pelikulang ginagawa akong tanga. Hello, kung tangahan lang naman, I can do that by myself 'noh. Charot.

Pero hindi ako masyadong choosy. All I ask from a movie is that delivers what it promised. I can enjoy a kababawan movie just as easily as a wellmade wasakan-hugot movie. The key is managing my expectation. Better yet exceeding it. Ilang beses na bang ginamit yung linyang "pinaghirapan po namin ito" sa promo ng movie tapos pag pinanood eh halatang puke-pukeng effort lang ang ginawa? Mga pohtah kayo.

As a reviewer, same din ang hanap ko, kasi parang hindi mo naman mapaghihiway ang viewer sa reviewer. Mas mabubusi lang siguro. My reviews are experiential rather than technical pero nangyayari pa rin na paglabas ko ng 
sine parang OK naman sa akin yung film, pero habang sinusulat ko na yung review at kinukutkot ko na, ayyy parang ayoko na pala siya.

Downside of watching a movie you plan to review, hindi ka maka-sitback and relax kasi nagbubusisi ka na habang nanonood or may biglang papasok sa isip mo for your review na kailangan mong alalahanin yung phrasing at yung context ng eksena wherein you got the insight.

Also, kahit paano, nagtatry naman akong i-expand ang utak ko as a reviewer. Nagbasa-basa rin naman na ako ng ibang movie reviews online, nag-aaral maging mas kritikal sa panunuri, at nanonood nang nanonood nang nanonood.

So oo, though "kneejerkcritic" ang blog name ko at maraming kneejerk reactions akong isinusulat, hindi naman kneejerk ang pagpapublish ko ng reviews. Pinag-iisipan ko pa rin naman ito as a whole kahit paano.

There are still some considerations na binabalanse ko. Like if indie film ito or teatro, bilang advocate, mas effusive ako sa sa praises at medyo mas kind ako sa panchachaka kung pangit. Sasabihin ko medyo pangit lang. Hahaha.

But mainstream films are fair game. Go to town ako diyan, especially kung obvious money-grab ang intention ng pelikula. Chakahin natin nang bonggang-bongga yan when deserved! I will never say na nagandahan ako sa movie dahil lang sinabi ng ibang respected critics na maganda yung movie. Kung nachakahan ako, sasabihin kong nachakahan ako. Fight me. Char.

Tulad ng review ko sa Dawn Zulueta and Piolo Pascual starrer na Love Me Tomorrow [dinirhe ni Gino M. Santos, ABS-CBN Film Productions at Star Cinema, 2016] (Pig. 4): 


\section{Panget.}

Maganda ang shots. Glossy siya, well-framed. Pero panget.

Isoli niyo pera ko, isoli niyo oras ko level na panget.

\#lovemetomorrow? Eh hindi ko nga siya like man lang today.

Ito yata yung pelikula na hindi ako masyadong nabother na chaka ang audio sa SM Cinemas kasi at a certain point wala na akong pake sa dialogue dahil alam kong walang wawa.

Sayang yung visuals. Sayang yung charm ni Dawn Zululeta. Sayang ang abs ni Papa Piolo Pascual. Pohtang ina may Ana Abad Santos ka sa cast, ginawa lang flower vase sa gilid, anuvey?!!!

Honestly the best thing about the movie is the ending.... End na yung movie. Uwi na tayo. Da best.

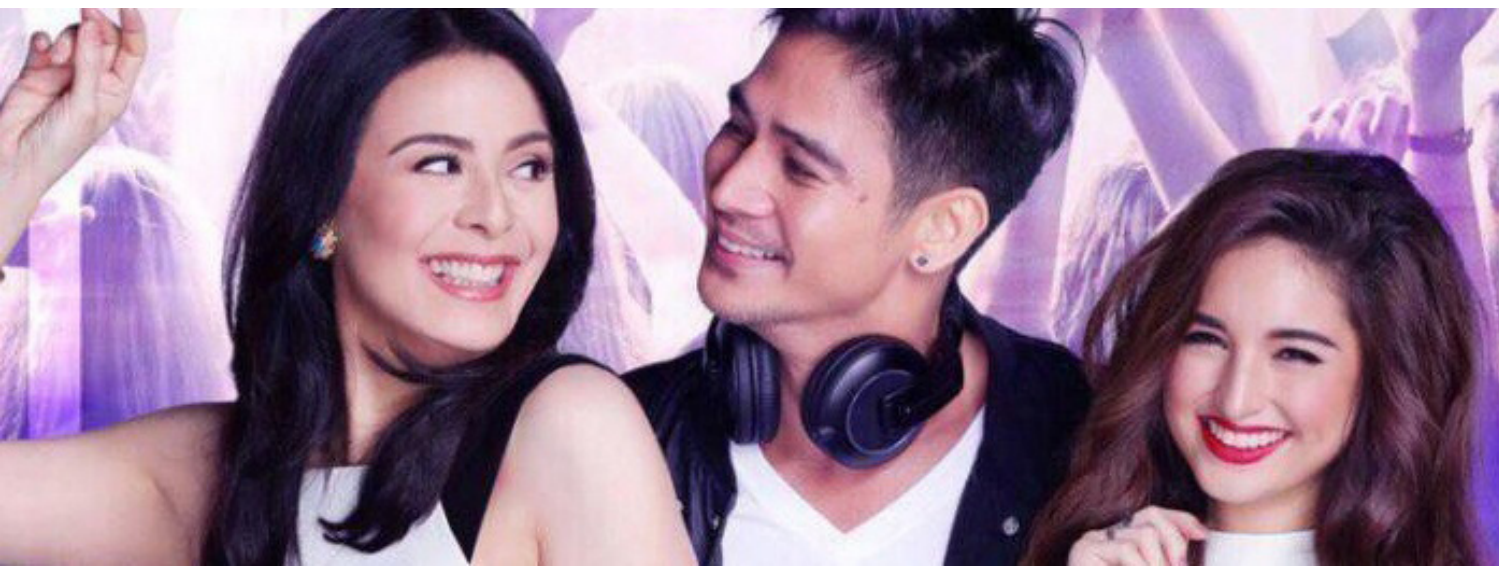

Pig. 4. Promo pic ng Love Me Tomorrow ni Gino M. Santos. (ABSCBN Film Productions at Star Cinema, 2016) 
Which now brings me to the language I use which I would describe as bekinese na balajurs nag nagpapaka-learned. Char.

Though there are very few reviewers who deliver their critiques in a manner similar to mine, my choice of vocabulary is not unique. I have been inspired by not just a few blogs using the same mode of expression. The now inactive blog of Mandaya Moore comes to mind. So basically, sabi nga ni Cherie Gil, "you're nothing but a second-rate, trying-hard copycat?"

It was a conscious decision for me to use and continue using bekinese as the primary mode of communication in my blog.

Una, sabi nga ng mga pokpok na stripper sa Gypsy [dinirhe ni Mervyn LeRoy, Mervyn LeRoy Productions, 1962], “you gotta have a gimmick” (Pigura 5), at yun yung gimmick ko. When I started the blog, all I wanted was to express myself and be read. Yung desire to be of service sa industry came later, and by that time medyo established na yung character at brand nung blog. May brand-brand pa talagang nalalaman 'noh?

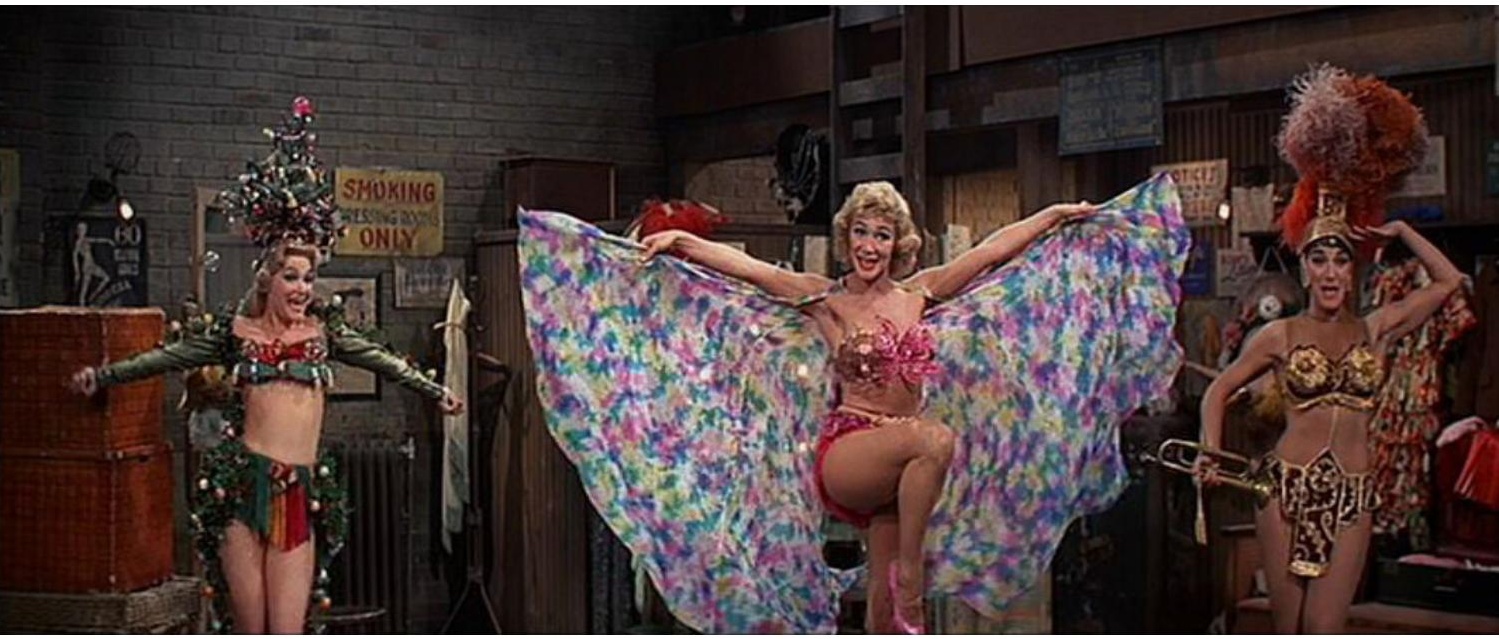

Pig. 5. Still pic ng "You Gotta Have a Gimmick" number sa Gypsy ni Mervyn LeRoy. (Mervyn LeRoy Productions, 1962) 
Second, since I was trying to use my voice to serve the industry, my movie reviews had to be read and shared. And to be read and shared in this day and age, you have to entertain. Or at least shock and awe.

Third, I believe that movie reviews need to be read and enjoyed by the masses and hindi yung iilan lang nang nakakabasa at nakakaintindi. Ano 'to, paramihan ba ng magamit ng multisyllabic words ang labanan?

Fourth, with using street and bekinese language, I try to be their eyes and their voice. Hopefully the reviews would encourage the masa to go and watch, to inform them na merong ganitong mga klaseng pelikula available for them to watch. And maybe, just maybe even educate them to be more critical sa panonood at more discerning sa choices ng pelikulang susuportahan nila.

Fifth, I love the exercise. Bet ko yung finding ways to see a particular movie with a unique perspective. Or retelling the story in a different, more colorful light. Kung hindi ko sila mahikayat na manood ng mga pelikula, then maybe the review itself might entertain you and make you laugh.

At kung hindi kayo natawa, eh di pakyu kayo!

Char. Shock and awe. 